\title{
Pengaruh Facilitation Condition terhadap Niat Menggunakan Sistem Informasi Manajemen Hasil Pengawasan (SIM HP) dengan Harapan Usaha dan Harapan Kinerja Sebagai Variabel Intervening (Studi Kasus Pada Inspektorat Provinsi Banten)
}

\author{
Roza Mulyadi \\ Lili Sugeng Wiyantoro \\ (Fakultas Ekonomi dan Bisnis - Universitas Sultan Ageng Tirtayasa)
}

\begin{abstract}
This study examines the effect of facilitating conditions and examine how the mediating role of business expectations and the expectations of the performance of the intention to use Management Information System Monitoring Results (MIS MR). This research was conducted at the Institute Inspectorate Banten Province as the research object. In this study a total of 37 questionnaires distributed questionnaires. Of these questionnaires were not returned the questionnaire amounted to 2, or 5.4\%, and totaled 35 questionnaires were returned questionnaires or $94.6 \%$ of respondents who restore, and questionnaires that can be processed amount to 35 or 94.6\%. Researchers used the test SEM (Structural Equation Modelling) by using test equipment SmartPLS.

This study uses survey research with primary data collection using the questionnaire. The results showed (1) Facilitation Condition positive effect on business expectations (2) Facilitation Condition positive effect on performance expectations (3) Facilitation Condition positive effect on Facilitation Condition positive effect on (4) Hope effort has positive influence on the intention to use Management Information System Results Supervision (MIS MR) (5) Hope's performance a positive influence on the intention to use Management Information System Monitoring Results (MIS MR) (6) Hope successful attempt to mediate Facilitation Condition intention of using Management Information System Monitoring Results (MIS MR) (7) Hope the performance condition is successfully mediate facilitation of the intention of using Management Information System Monitoring Results (MIS MR).
\end{abstract}

Keywords: Facilitation Condition, Effort Expecation, Performance Expectation, and Intention to Use Management Information System Monitoring Results (MIS MR)

\section{PENDAHULUAN}

Sebagai badan pengawasan terhadap pelaksanaan urusan pemerintahan di daerah, Inspektorat sering menemukan adanya penyimpangan atau penyelewengan yang berkaitan dengan kebijakan dan prosedur yang ditetapkan oleh manajemen puncak (kepala daerah). Baik kebijakan dan prosedur dalam urusan keuangan, tata kerja atau hal-hal yang berhubungan dengan sumber daya manusia serta kemajuan sistem informasi yang berkaitan dengan dinas atau lembaga yang sedang diperiksa. Dengan informasi yang handal, maka dapat memperkecil terjadinya kesalahan pengambilan keputusan atau tindakan dan juga menjadi sumber untuk melakukan pemantauan dan pengendalian. Kemajuan teknologi di bidang hardware (perangkat keras) maupun software (perangkat lunak), berimbas pada berkembangnya pemanfaatan media informasi. Khususnya pemanfaatan yang ditanam prosesor canggih sehingga mampu memproses sebuah aplikasi secara cepat dan dapat diakses oleh para penggunanya. Inilah teknologi yang dimanfaatkan untuk membangun sebuah aplikasi sistem informasi untuk memproses data hasil pengawasan atau lebih dikenal Sistem Informasi Manajemen Hasil Pengawasan (SIM HP) 
Fenomena berkaitan pengawasan, yang terjadi saat ini berdasarkan BPK RI Provinsi Banten tahun ini 2015 mendapatkan opini Disclaimer atau Tidak Menyatakan Pendapat (TMP). Beberapa permasalahan sehingga Provinsi Banten kembali mendapatkan disclaimer diantaranya belanja perawatan kendaraan bermotor pada Biro Perlengkapan dan Aset Daerah Setda tidak dapat didukung bukti pertanggung jawaban yang valid 3,1 miliar, Dana hibah dilakukan tanpa proses verifikasi pada pengajuan proposal pengajuan 9,76 M (Sumber BPK RI dalam Banten Raya). Sistem Informasi Manajemen Hasil Pengawasan (SIM HP) diharapkan dapat meningkatkan kinerja auditor Inspektorat dalam mengawasi Satuan Kerja Perangkat Daerah (SKPD) Provinsi Banten. Sehingga hal tersebut tidak terulang lagi untuk tahun kedepannya. Oleh karena itu Inspektorat Provinsi Banten bekerjasama dengan Badan Pengawasan Keuangan dan Pembangunan (BPKP) Perwakilan Provinsi Banten untuk memulai kerjasama penerapan aplikasi SIM HP sebagai langkah maju dalam melakukan tata kelola hasil pengawasan aparat pengawas. Data hasil pengawasan merupakan salah satu informasi penting yang diperlukan oleh pimpinan sebagai bahan pengambilan keputusan karena itu data hasil pengawasan harus tersedia secara cepat, tepat, akurat dan dapat dipertanggung jawabkan. Dengan dimilikinya data hasil pengawasan berbasis aplikasi SIM HP tersebut akan semakin memuluskan Pemerintah Provinsi Banten memperoleh Opini Wajar Tanpa Pengecualian (WTP) dari BPK dalam mewujudkan Good Governance (Sumber:www.bpkp.go.id).Fenomena tersebut merupakan contoh niat menggunakan SIM HP yang dilakukan oleh auditor Inspektorat Provinsi Banten. Hal ini berdampak positif terhadap suatu Sistem Informasi Manajemen Hasil Pengawasan (SIM HP) yang terpadu dan memudahkan Inspektorat dalam mengelola dan memantau hasil-hasil pemeriksaan, termasuk tindak lanjut yang telah dilakukan oleh auditan atau objek pemeriksaan.

Penerapan sistem informasi dalam pelaksanaan pengawasan akan sangat bermanfaat bagi auditor karena dengan teknik tersebut auditor dapat melaksanakan pengawasan. Oleh karena itu auditor menggunakan teknik sistem inforamasi berbantuan komputer dalam menghasilkan laporan pengawasan. Disamping itu, dengan menggunakan teknik tersebut pelaksanaan pengawasan menjadi lebih efektif dan efisien. Dalam lingkungan yang terkomputerisasi harus diterapkan pengendalian untuk mengurangi resiko kesalahan, untuk memastikan bahwa data yang dihasilkan benar-benar akurat. Perubahan dalam pengolahan dan metode pengendalian ini telah memicu metode baru dalam pengawasan. Auditor dituntut untuk menggunakan software khusus yang didesain untuk melaksanakan audit atas aplikasiaplikasi yang terkomputerisasi. Dengan semakin berkembangnya teknologi informasi yang mempengaruhi cara kerja auditor, kebutuhan auditor akan aplikasi audit menjadi semakin besar (Pusdiklatwas BPKP, 2008).

Penelitian ini akan menguji faktor-faktor apa saja yang mempengaruhi penerimaan auditor terhadap perangkat lunak (software) audit dengan mengadaptasi Technology Acceptance Model (TAM) dengan menambah tiga variabel eksternal. Variabel tersebut adalah tiga variabel eksternal dari (Curtis dan Elizabeth, 2014) yaitu harapan kinerja, harapan usaha, kondisi memfasilitasi. Model penerimaan teknologi (Technology Acceptance Model atau TAM) merupakan suatu model penerimaan sistem teknologi informasi yang akan digunakan oleh pemakai. Model penerimaan teknologi atau Technology Acceptance Model (TAM) dikembangkan oleh (Davis, 1989) berdasarkan model Theory of Reasoned Action (TRA).Penelitian ini menggunakan model terintegrasi yakni penggabungan teori sistem informasi yang sangat terkenal. Ketiga teori tersebut adalah model UTAUT, TRA dan TAM model kesuksesan sistem informasi. Ketiga model tersebut menggunakan variabel dependen hampir sama yakni niat untuk menggunakan suatu sistem, model UTAUT, TRA dan TAM menggunakan istilah "behavioural intention" dan menggunakan istilah "intention to use" atau "use". 
Penelitian ini merupakan modifikasi dari penelitian Curtisdan Elizabeth (2014) dan Venkatesh (2003), tentang "Modeling voluntary CAAT utilization decisions in auditing".Perbedaan penelitian ini dengan penelitian sebelumnya yaitu penelitian Curtisdan Elizabeth(2014) menunjukan hasil bahwa harapan kinerja, harapan usaha, dan kondisi memfasilitasi berpengaruh terhadap niat menggunakan sistem informasi, sedangkan penelitian terdahulu oleh Gonzalez et al (2012) menunjukan hasil bahwa angka persepsi harapan usaha dan harapan kinerja adalah pengaruh yang signifikan terhadap behavioral intention terhadap penggunaa sistem informasi.

\section{KERANGKA TEORI DAN PENGEMBANGAN HIPOTESIS Theory Reasoned Action (TRA)}

Theory Reasoned Action pertama kali dicetuskan oleh Ajzen pada tahun 1980. Teori ini disusun menggunakan asumsi dasar bahwa manusia berperilaku dengan cara yang sadar dan mempertimbangkan segala informasi yang tersedia. Dalam TRA ini, Ajzen (1980) menyatakan bahwa niat seseorang untuk melakukan suatu perilaku menentukan akan dilakukan atau tidak dilakukannya perilaku tersebut.Theory of Reasoned Action atau teori tindakan beralasan atau teori aksi beralasan mengatakan bahwa sikap mempengaruhi perilaku melalui suatu proses pengambilan keputusan yang teliti akan beralasan dan dampaknya terbatas hanya pada tiga hal. Pertama, perilaku tidak banyak ditentukan oleh sikap umum tetapi oleh sikap yang spesifik terhadap sesuatu. Kedua, perilaku tidak hanya dipengaruhi oleh sikap tetapi juga oleh norma subyektif (subjective norms) yaitu keyakinan kita mengenai apa yang orang lain inginkan agar kita lakukan. Ketiga, sikap terhadap suatu perilaku bersamasama norma subyektif membentuk suatu niat untuk berperilaku tertentu. Intention atau niat merupakan fungsi dari dua niat dasar yaitu sikap individu terhadap perilaku (merupakan aspek pribadi) dan persepsi individu terhadap tekanan sosial untuk melakukan atau untuk tidak melakukan perilaku yang disebut dengan norma subyektif.

\section{The Unified Theory of Acceptance and Use of Technology (UTAUT)}

The Unified Theory of Acceptance and Use of Technology (UTAUT) merupakan salah satu model terbaik untuk adopsi dan penggunaan teknologi informasi. Teori UTAUT disusun berdasarkan model-model penerimaan teknologi sebelumnya seperti Theory of Reason Action (TRA) dan terutama adalah model Technology of Acceptance Model (TAM). UTAUT bertujuan menjelaskan niat seseorang untuk menggunakan atau tidak menggunakan suatu sistem informasi teknologi dan perilaku pengguna berikutnya (Venkatesh et al, 2003).Model UTAUT memiliki empat konstruk yang memainkan peran penting sebagai niat langsung dari behavioral intention dan use behavior yaitu, harapan kinerja, harapan usaha, pengaruh sosial dan kondisi memfasilitasi. Teori penerimaan teknologi informasi UTAUT (Unified Theory of Acceptanceand and Use of Tecnology) mendasarkan pada teori-teori perilaku penggunaan teknologi dan penerimaan teknologi. Model teori ini bertujuan menjelaskan niat (intention) pengguna untuk menggunakan sistem informasi dan perilaku pengguna berikutnya. Model ini menjelaskan beberapa variabel diantaranya: harapan kinerja (performance expectancy) merupakan tindakan dimana seseorang percaya bahwa dengan menggunakan sistem informasi tersebut akan membantu seseorang untuk mencapai keuntungan dalam kinerja. Harapan usaha (effort expectancy) merupakan tingkat kemudahan yang dihubungkan dengan penggunaan suatu sistem. Faktor sosial (social influence) merupakan tingkat sejauh mana seorang individu memandang pentingnya faktor lingkungan kerjanya (dalam hal ini lingkup sosial) dalam penggunaan sistem baru, sehingga akan mempengaruhi atau menyakinkan dirinya bahwa dia juga harus menggunakan sistem baru tersebut. Kondisi memfasilitasi (facilitation condition) merupakan kepercayaan seseorang bahwa adanya fasilitas organisasi dan infrastruktur teknis yang ada digunakan untuk mendukung penggunaan sistem tersebut. Perilaku penggunaan (use 
behavior) merupakan intensitas atau frekuensi pemakai dalam menggunakan teknologi informasi.

\section{Teori Technology Acceptence Model (TAM)}

Penelitian ini didasarkan pada TAM yang dikembangkan oleh Davis(1989) dimana tingkat penerimaan pengguna teknologi informasi (information technology acceptance). Salah satu teori integrasi teknologi merupakan teori yang menganalisis dan memahami faktor-faktor yang mempengaruhi diterimanya penggunaan sistem informasi.TAM mendeskripsikan terdapat dua faktor yang secara dominan mempengaruhi niat menggunakan teknologi sistem informasi. Faktor pertama adalah persepsi pengguna terhadap manfaat teknologi (ease of use). Faktor kedua adalah persepsi pengguna terhadap kemudahan penggunaan teknologi sistem informasi (usefulness). Selanjutnya kemauan untuk niat menggunakan sistem informasi akan mempengaruhi penggunaan teknologi sistem informasi yang sesungguhnya.

\section{Pengaruh Kondisi Memfasilitasi terhadap Niat Menggunakan Sistem Informasi Manajemen Hasil Pengawasan (SIM HP)}

Dalam UTAUT, efek kondisi memfasilitasi pada niat berpengaruh signifikan ketika kedua harapan kinerja dan harapan usaha hadir dalam model. Dalam satu-satunya uji penuh UTAUT dalam pengaturan akuntansi.Gonzalez et al (2012) menemukan efek yang signifikan dari kondisi memfasilitasi pada niat untuk menggunakan teknik audit berbantuan komputer dalam pengaturan audit internal. Venkatesh dan Bala (2008) mengusulkan alternatif untuk kondisi memfasilitasi dalam model TAM mereka, menunjukkan bahwa kondisi memfasilitasi secara langsung terkait dengan niat menggunakan melalui jalur persepsi kemudahan penggunaan harapan usaha ke manfaat yang dirasakan harapan kinerja. Hasil model yang mendukung gagasan harapan usaha penuh memediasi hubungan antara kondisi memfasilitasi dan faktor lainnya dalam model UTAUT disesuaikan dengan adopsi sukarela teknik audit berbantuan komputer. Pelatihan dan peningkatan bantuan teknis, kemudahan penggunaan persepsi harus meningkat juga. Dengan demikian, persepsi auditor dari harapan usaha dipengaruhi oleh persepsi mereka tentang kondisi memfasilitasi (Bedard et al, 2003).Dengan adanya kondisi memfasilitasi semakin memudahkan auditor dalam menggunakan sistem informasi seperti adanya tersedia tenaga ahli, komputer, dukungan atasan, dukungan rekan kerja dan semakin meningkatkan kepercayaan auditor dalam menggunakan sistem informasi untuk keuntungan dalam meningkatkan kinerjanya (Curtis dan Elizabeth, 2014). Seperti yang ditunjukan pada hasil penelitian terdahulu mempunyai hubungan hipotesis Dwi et al (2009) yang menyatakan bahwa kondisi memfasilitasi mempunyai pengaruh yang positif terhadap minat pemanfaatan sistem informasi. Berdasarkan uraian diatas, maka peneliti ingin menguji hubungan antara kondisi memfasilitasi dengan niat menggunakan SIM HP. Oleh karena itu diajukan hipotesis:

H1a: Pengaruh kondisi memfasilitasi berpengaruh positif terhadap harapan usaha

H1b:Pengaruh kondisi memfasilitasi berpengaruh positif terhadap harapan kinerja

H1c: Kondisi memfasilitasi berpengaruh positif terhadap niat menggunakan Sistem Informasi Manajemen Hasil Pengawasan (SIM HP).

\section{Pengaruh Harapan Usaha terhadap Niat Menggunakan Sistem Informasi Manajemen Hasil Pengawasan (SIM HP)}

Gonzalez et al (2012) menemukan harapan usaha terkait dengan niat untuk menggunakan dalam konteks audit internal. Bedard et al (2003) menemukan persepsi kemudahan penggunaan berpengaruh positif terkait dengan niat untuk memanfaatkan perangkat lunak audit akuntan publik. Pennington et al (2006) menemukan kelebihan kualitatif menengahi hubungan antara kemudahan penggunaan dan niat menggunakan. Oleh 
karena itu, mengusulkan bahwa tingkat harapan usaha pada keterlibatan harus berdampak pada evaluasi kinerja mengharapkan untuk mencapai, sehingga harapan usaha memediasi hubungan kondisi memfasilitasi terhadap niat menggunakan sistem informasi. Seperti yang ditunjukan pada hasil penelitian terdahulu mempunyai hubungan hipotesis Dwi et al (2009) yang menyatakan bahwa harapan usaha mempunyai pengaruh yang positif terhadap minat pemanfaatan sistem informasi. Berdasarkan uraian diatas, maka peneliti ingin menguji hubungan antara harapan usaha dengan niat menggunakan SIM HP. Oleh karena itu diajukan hipotesis:

H2: Harapan usaha berpengaruh positif terhadap niat menggunakan Sistem Informasi Manajemen Hasil Pengawasan (SIM HP).

\section{Pengaruh Harapan Kinerja terhadap Niat Menggunakan Sistem Informasi Manajemen Hasil Pengawasan (SIM HP)}

Pengaruh antara harapan kinerja dan niat menggunakan sistem informasi dikatakan positif apabila keyakinan seorang individu akan penggunaan sistem informasi yang dapat mempermudah kinerjanya itu tinggi, maka akan tinggi pula minat pemanfaatan sistem informasi pada individu tersebut. Hal harapan kinerja penggunaan sistem informasi ini mengacu pada Theory of Reasoning Action (TRA) yang menyatakan bahwa seorang individu akan memanfaatkan teknologi informasi dengan alasan bahwa teknologi atau sistem tersebut akan menghasilkan manfaat bagi dirinya (Davis et al, 1989). Seperti yang ditunjukan pada hasil penelitian terdahulu mempunyai hubungan hipotesis Dwi et al (2009) yang menyatakan bahwa harapan kinerja mempunyai pengaruh yang positif terhadap minat pemanfaatan sistem informasi. Berdasarkan uraian diatas, maka peneliti ingin menguji hubungan antara harapan kinerja dengan niat menggunakan SIM HP. Oleh karena itu diajukan hipotesis:

H3:Harapan kinerja berpengaruh positif terhadap niat menggunakan Sistem Informasi Manajemen Hasil Pengawasan (SIM HP).

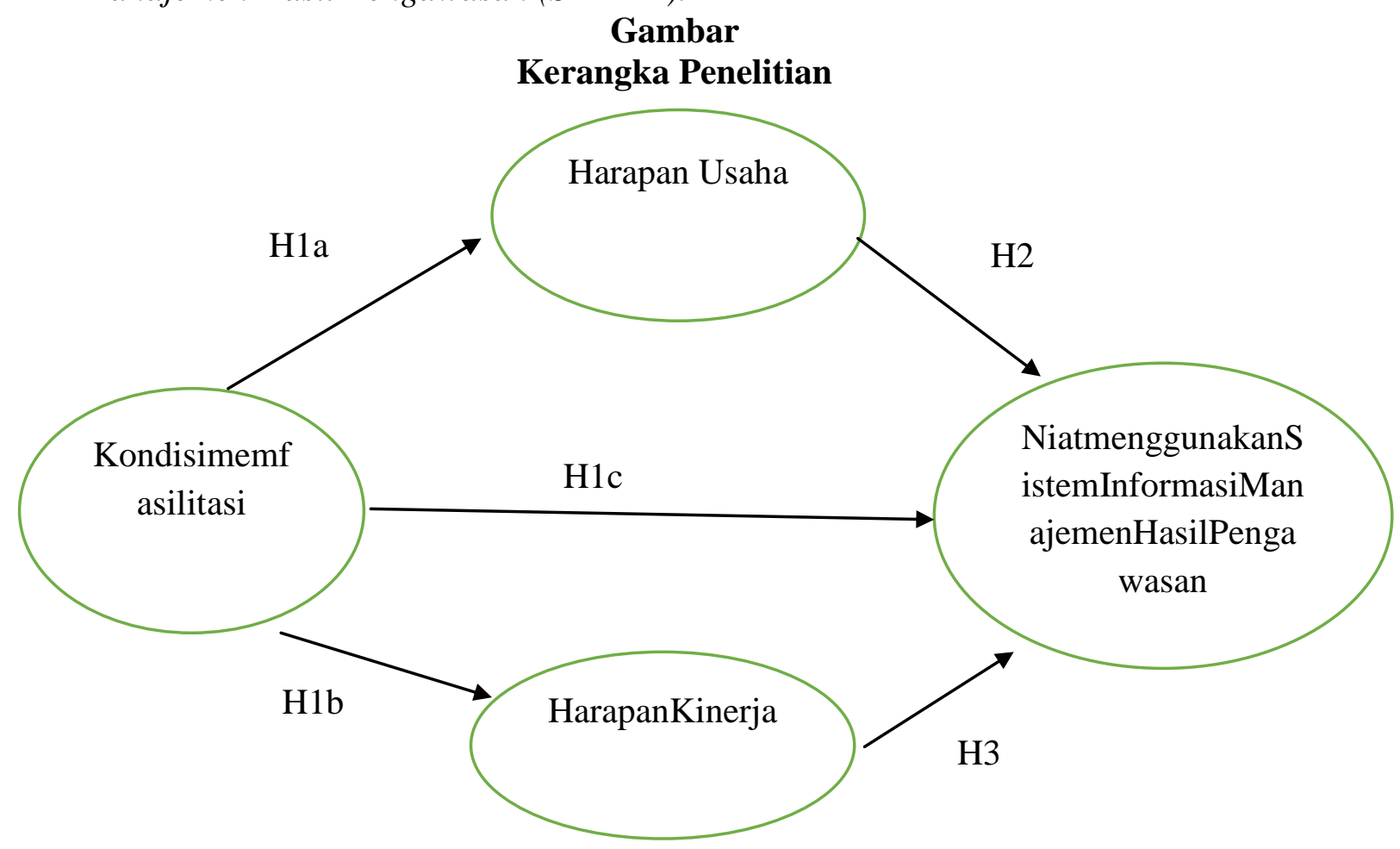

Sumber: Curtis dan Elizabeth (2014) dan Venkatesh (2003) 


\section{METODELOGI PENELITIAN}

\section{Populasi, Sampel, dan Teknik Penarikan Sampel}

Populasi penelitian ini adalah Auditor Inspektorat Provinsi Banten dengan jumlah 37 auditor dengan rata-rata pengalaman kerja 5 tahun. Tingkatan auditor di Inspektorat Provinsi Banten terdiri dari: 1) Auditor Terampil; Auditor Pelaksana, Auditor Pelaksana Lanjutan dan Auditor Penyelia, 2) Auditor Ahli; Auditor Ahli Pertama, Auditor Ahli Muda dan Auditor Ahli Madya. . Dalam penelitian ini teknik penentuan sampel yang digunakan adalah sampel jenuh.

\section{Operasional Variabel}

Sesuai dengan identifikasi masalah yang akan dikaji dan model yang disusun maka operasional variable yang digunakan adalah sebagai berikut:

Tabel Operasional dan Pengukuran Variabel

\begin{tabular}{|c|c|c|c|}
\hline No & Variabel & Indikator & Skala \\
\hline 1. & Kondisi memfasilitasi & $\begin{array}{l}\text {-Sumber daya organisasi } \\
\text {-Pelatihan } \\
\text {-Tenaga Ahli } \\
\text {-Dukungan atasan } \\
\text { Curtis dan Elizabeth (2014) }\end{array}$ & Ordinal \\
\hline 2. & Harapan Kinerja & $\begin{array}{l}\text {-Meningkatkan kualitas pengawasan } \\
\text { Menyelesaikan pekerjaan lebih cepat } \\
\text {-Meningkatkan produktivitas } \\
\text { Curtis dan Elizabeth (2014) }\end{array}$ & Ordinal \\
\hline 3. & Harapan Usaha & $\begin{array}{l}\text {-Kemudahan interaksi } \\
\text {-Kerumitan } \\
\text {-Usaha yang dilakukan } \\
\text { Curtis dan Elizabeth (2014) }\end{array}$ & Ordinal \\
\hline 4 & $\begin{array}{l}\text { Niat Menggunakan } \\
\text { Informasi Manajemen } \\
\text { Pengawasan (SIM HP) }\end{array}$ & $\begin{array}{l}\text {-Keinginan } \\
\text {-Berencana } \\
\text {-Prediksi } \\
\text {-Berniat } \\
\text { Curtis dan Elizabeth (2014) }\end{array}$ & Ordinal \\
\hline
\end{tabular}

\section{HASIL PENELITIAN DAN PEMBAHASAN}

\section{Analisis Data}

Analisis data dalam penelitian ini terdiri dari statistik deskriptif, Uji kualitas data pada penelitian ini meliputi uji validitas yang diukur dengan Average Variance Extracted (AVE) dan uji reliabilitas diukur dengan composite reliability dan cronbach alpha dengan menggunakan software Partial Least Square (PLS), dan pengujian hipotesis dengan pendekatan Structural Equation Model (SEM) dengan menggunakan software Partial Least Square (PLS) yaitu menilai Outer Model atau Model Pengukuran dan menilai Inner Model atau Structural Model. Pengujian hipotesis mediasi dapat dilakukan dengan prosedur yang dikembangkan oleh Sobel (1982) dan dikenal dengan uji Sobel (sobel test). Responden dalam penelitian ini adalah seluruh auditor Inspektorat yang berniat menggunakan Sistem Informasi Manajemen Hasil Pengawasan (SIM HP) dengan data yang dapat diolah sebanyak 35 dari 37 yang disebar. 


\section{Kualitas Data}

Penelitian ini sudah melalui Pengujian uji validitas Uji Reliabilitas, semua data yang digunakan valid dan reliable, dengan outer modelyaitu convergent validity yang dilihat dengan nilai square root of Average Variance Extracted ( $A V E$ ) masing-masing konstruk.

\section{Pengujian Hipotesis dan Pembahasan}

Menilai Outer Model(Measurement Model)

\section{Gambar}

Full Model Structural Partial Least Square

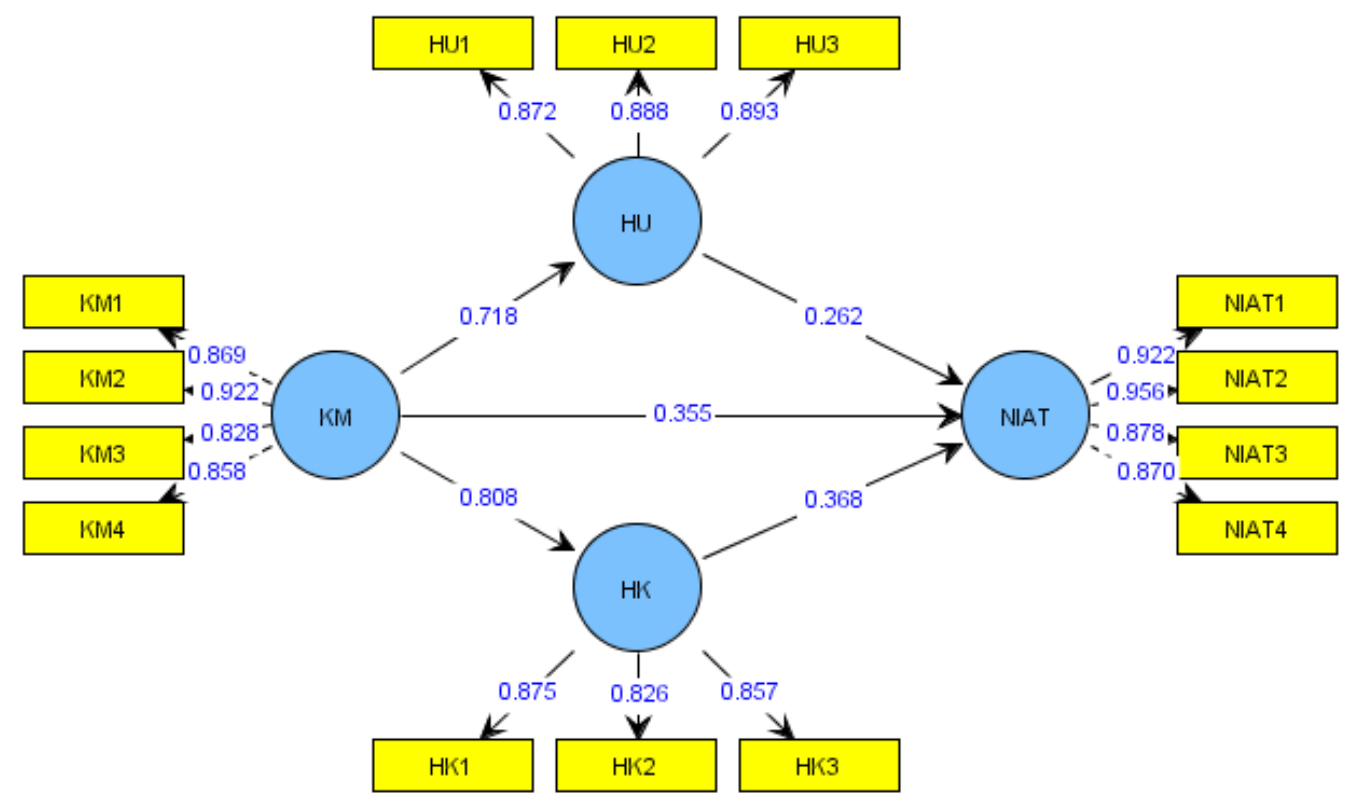

Keterangan

HU : Harapan Usaha, HK : Harapan Kinerja, KM : Kondisi Memfasilitasi, NIAT : Niat Menggunakan Sistem Informasi Manajemen Hasil Pengawasan (SIM HP)

Pengujian Hipotesis melalui Inner Model

Tabel Result for inner weight

\begin{tabular}{cccccc}
\hline H & & $\begin{array}{c}\text { Original } \\
\text { Sample } \\
\text { Estimate }\end{array}$ & $\begin{array}{c}\text { Mean of } \\
\text { Subsamples }\end{array}$ & $\begin{array}{c}\text { Standard } \\
\text { Deviation }\end{array}$ & T-Statistic \\
\hline H1 & KM -> HU & 0,718 & 0,730 & 0,075 & 9,574 \\
H2 & KM -> HK & 0,808 & 0,811 & 0,052 & 15,456 \\
H3 & HU -> NIAT & 0,262 & 0,256 & 0,095 & 2,762 \\
H4 & HK -> NIAT & 0,368 & 0,361 & 0,148 & 2,491 \\
H5 & KM -> NIAT & 0,355 & 0,369 & 0,128 & 2,840 \\
\hline
\end{tabular}

Berdasarkan Tabel diatas terlihat bahwa pengaruh KM terhadap HU positif 0,718 dan signifikan pada $(9,574>1,96)$. Pengaruh KM terhadap HK positif 0,808 dan signifikan pada $(15,456>1,96)$. Pengaruh HU terhadap NIAT positif 0,262 dan signifikan pada $(2,762>1,96)$. Pengaruh HK terhadap NIAT positif 0,368 dan signifikan pada $(2,491>1,96)$. Dan pengaruh 
KM terhadap NIAT positif 0,355 dan signifikan pada $(2,840>1,96)$. Dalam menilai model dengan PLS dimulai dengan melihat $R$-Square untuk setiap variabel laten dependen.

\section{Tabel R-Square}

\begin{tabular}{cc}
\hline & R-square \\
\hline HU & 0,516 \\
HK & 0,653 \\
KM & \\
NIAT & 0,830 \\
\hline
\end{tabular}

Tabel diatas menunjukkan nilai $R$-square harapan usaha sebesar 0,516 , harapan kinerja sebesar 0,653, dan niatsebesar 0,830. Semakin tinggi $R$-square, maka semakin besar variabel independen tersebut dapat menjelaskan variabel dependen sehingga semakin baik persamaan struktural. Variabel harapan usaha memiliki nilai $R$-square sebesar 0,516 yang berarti 51,6\% dipengaruhi oleh variabel kondisi memfasilitasi. Variabel harapan kinerja sebesar 0,653 yang berarti 65,3\% yang dipengaruhi oleh variabel kondisi memfasilitasi. Variabel niat sebesar 0,830 yang dipengaruhi oleh kondisi memfasilitasi, harapan usaha dan harapan kinerja sedangkan sisanya dipengaruhi oleh variabel yang lain.

\section{Pengaruh Kondisi Memfasilitasi terhadap Harapan Usaha}

Dari hasil diatas dapat dinyatakan bahwa hipotesis 1 diterima.Hasil penelitian ini konsisten dengan penelitian Curtis dan Elizabeth (2014) bahwa kondisi memfasilitasi memainkan peran dalam harapan usaha. Selanjutnya hasil hipotesis ini juga sesuai dengan kenyataan di lapangan yang dapat dilihat dari jawaban responden pada kuesioner variabel kondisi memfasilitasi yaitu jawaban responden dengan skala ordinal menyatakan bahwa hasil indikator kondisi memfasilitasi terhadap harapan usaha yang tertinggi adalah pelatihan, artinya pelatihan memudahkan auditor Inspektorat Provinsi Banten terhadap harapan usaha sehingga kinerja auditor Inspektorat Provinsi Banten akan lebih baik. Sejauh mana auditor masalah pelaksanaan tergantung pada kualitas pelatihan yang diterima dan bantuan teknologi informasi diharapkan selama pelaksanaan, kemudahan penggunaan persepsi auditor dari harapan usaha dipengaruhi oleh persepsi mereka tentang kondisi memfasilitasi. Semakin baik kondisi memfasilitasi seperti pelatihan yang akan di berikan kepada auditor maka semakin memudahkan harapan usaha.

\section{Pengaruh Memfasilitasi terhadap Harapan Kinerja}

Dari hasil diatas dapat dinyatakan bahwa hipotesis 2 diterima.Hasil penelitian ini mendukung penelitian sebelumnya (Venkatesh et al, 2003) memberikan bukti empiris bahwa sejauh mana seorang individu percaya bahwa infrastruktur organisasi dan teknis ada mendukung dapat penggunaan sistem. Hasil hipotesis ini juga sesuai dengan kenyataan di lapangan yang dapat dilihat dari jawaban responden pada kuesioner variabel kondisi memfasilitasi yaitu jawaban responden dengan skala ordinal menyatakan bahwa hasil indikator kondisi memfasilitasi terhadap harapan kinerja yang tertinggi adalah pelatihan, artinya pelatihan memberikan manfaat dalam harapan kinerja. Semakin baik kondisi memfasilitasi sarana dan prasarana yang akan diberikan kepada auditor maka semakin memberikan manfaat auditor terhadap harapan kinerja sehingga kinerja auditor Inspektorat Provinsi Banten semakin baik terhadap pengawasan SKPD di Provinsi Banten dalam analisis, evaluasi, penyusunan dan menindaklanjuti laporan kegiatan hasil pengawasan Inspektorat sehingga sistem informasi ini akan memberikan manfaat dalam harapan kinerja. Dalam UTAUT, efek kondisi memfasilitasipada niat berpengaruh signifikan ketika kedua harapan kinerja dan harapan usaha hadir dalam model. Dalam satu-satunya uji penuh UTAUT dalam pengaturan akuntansi, Gonzalez et al (2012) menemukan efek yang signifikan dari kondisi 
memfasilitasi pada niat untuk menggunakan teknik audit berbantuan komputerdalam pengaturan audit internal.

\section{Pengaruh Memfasilitasi terhadap Niat Menggunakan Sistem Informasi Manajemen Hasil Pengawasan (SIM HP)}

Dari hasil diatas dapat dinyatakan bahwa hipotesis 3 diterima. Selanjutnya hasil hipotesis ini juga sesuai dengan kenyataan di lapangan yang dapat dilihat dari jawaban responden pada kuesioner variabel kondisi memfasilitasi yaitu jawaban responden dengan skala ordinalmenyatakan bahwa di Lembaga Inspektorat Provinsi Banten memiliki sumber daya seperti komputer, Inspektorat Provinsi Banten akan melakukan pelatihan sebelum menggunakan SIM HP, terdapat tenaga ahli yang mendukung dalam penggunaan SIM HP dan dukungan atasan serta rekan kerja memberikan dukungan sehingga pengawasan sebagai salah satu fungsi manajemen untuk menjamin agar pelaksanaan kegiatan pengawasam berjalan sesuai dengan ketentuan dan peraturan perundang-undangan yang berlaku, sehingga tujuan organisasi dapat tercapai secara efektif dan efesien sesuai dengan yang telah ditetapkan.Sesuai tugas pokok dan fungsinya sebagai Instansi pengawasan, Inspektorat Provinsi Banten telah menetapkan tujuan yang dicapai seperti, meningkatnya kualitas laporan keuangan Pemerintah Daerah dan SKPD dilingkungan Pemerintah Provinsi Banten, meningkatkan akuntabilitas keuangan dan Kinerja Instansi Pemerintah Lingkup Pemerintah Provinsi Banten dan meningkatnya kapasitas sumber daya manusia Inspektorat Provinsi Banten.Hasil penelitian ini sama dengan hasil penelitian yang dilakukan Dwi et al (2009) bahwa adanya rasa nyaman dalam bekerja merupakan contoh faktor yang membuat responden memutuskan untuk memanfaatkan sistem informasi dalam menyelesaikan pekerjaannya. Dengan semakin banyaknya infrastruktur (sarana dan prasarana) organisasi dan teknis yang ada, maka responden akan semakin cenderung memanfaatkan sistem informasi.

\section{Pengaruh Harapan Usaha terhadap Niat Menggunakan Sistem Informasi Manajemen Hasil Pengawasan (SIM HP)}

Dari hasil diatas dapat dinyatakan bahwa hipotesis 4 diterima. Hasil hipotesis ini juga sesuai dengan kenyataan dilapangan yang dapat dilihat dari jawaban responden pada kuesioner variabel harapan usaha yaitu jawaban responden dengan skala ordinal menyatakan bahwa hasil indikator harapan usaha terhadap niat menggunakan Sistem Informasi Manajemen Hasil Pengawasan (SIM HP) tertinggi adalah usaha yang dilakukan, artinya semakin giat auditor melakukan usaha pelatihan maka semakin mudah auditor dalam menggunakan Sistem Informasi Manajemen Hasil Pengawasan (SIM HP). Munculnya SIM HP dapat diharapkan perubahan pada sifat audit memecahkan banyak kekurangan dalam kerangka sistem informasi sehingga meningkatkan kualitas pengawasan. Dengan adanya dukungan organsisasi seperti pelatihan pembelajaran mengenai penggunaan SIM HP memudahkan auditor untuk menggunakan.Semakin baik pelatihan yang di berikan kepada auditor seperti cara-cara penggunaan, merancang struktur database, memasukan kode per laporan dan informasi lain terkait penggunaan SIM HP akan semakin memudahkan auditor untuk menggunakan (www.bpkp.go.id). Semakin mulus dan mudah auditor melakukan transisi dari pekerjaan secara manual ke penggunaan SIM HP akan menambah minat auditor untuk menggunakan.Hasil penelitian ini mendukung penelitian sebelumnya memberikan bukti empiris bahwa harapan usaha merupakan tingkat kemudahan penggunaan sistem informasi yang akan mengurangi upaya (tenaga dan waktu) dalam melakukan pekerjaannya (Venkatesh et al,2003).

Pengaruh Harapan Kinerja terhadap Niat Menggunakan Sistem Informasi Manajemen Hasil Pengawasan (SIM HP) 
Harapan kinerja berpengaruh positif dan signifikan terhadap terhadap niat menggunakan Sistem Informasi Manajemen Hasil Pengawasan (SIM HP) yang ditampilkan dengan nilai original sample estimate sebesar 0,368 dan nilai t-statistik 2,491adalah lebih besar dari t-tabel yaitu 1,96. Dengan demikian hipotesis 5 diterima. Hasil hipotesis ini juga sesuai dengan kenyataan di lapangan yang dapat dilihat dari jawaban responden pada kuesioner variabel harapan kinerja yaitu jawaban responden dengan skala ordinal menyatakan bahwa hasil indikator harapan kinerja terhadap niat menggunakan Sistem Informasi Manajemen Hasil Pengawasan (SIM HP) tertinggi adalah meningkatkan kualitas pengawasan, artinya sistem informasi ini memberikan manfaat dalam meningkatkan kualitas pengawasan SKPD di lingkungan Provinsi Banten. Program peningkatan sistem pengawasan internal dan pengendalian pelaksanaan kebijakan. Kegiatan yang dilaksanakan seperti, pelaksanaan pengawasan internal secara berkala, penanganan kasus pengaduan di lingkungan pemerintah daerah, evaluasi berkala temuan hasil pengawasan, koordinasi pengawasan yang komprehensif dan evaluasi berkala hasil pengawasan sehingga sistem informasi ini memberikan manfaat untuk auditor Inspektorat dalam meningkatkan kinerja.Hasil penelitian ini mendukung penelitian sebelumnya harapan kinerja sebagai tingkat dimana seorang individu meyakini bahwa dengan menggunakan sistem akan membantu memberikan manfaat dalam meningkatkan kinerjanya(Venkatesh et al, 2003). Harapan kinerja penggunaan sistem informasi ini mengacu pada Theory of Reasoning Action (TRA) yang menyatakan bahwa seorang individu akan memanfaatkan teknologi informasi dengan alasan bahwa teknologi atau sistem tersebut akan menghasilkan manfaat bagi dirinya (Davis, 1989).

\section{Pengaruh Facilitation Condition terhadap Niat Menggunakan Sistem Informasi Manajemen Hasil Pengawasan (SIM HP) Melalui Harapan Usaha sebagai Variabel Intervening}

Pengujian hipotesis keenam untuk pengujian pengaruh tidak langsung variabel facilitation condition terhadap niat menggunakan Sistem Informasi Manajemen Hasil Pengawasan (SIM HP) melalui harapan usaha dilakukan dengan terlebih dahulu mengetahui hasil pengujian terhadap pengaruh harapan usaha terhadap niat menggunakan Sistem Informasi Manajemen Hasil Pengawasan (SIM HP). Pengujian pengaruh mediasi dilakukan dengan menggunakan rumus sobel. Hasil pengujian pengaruh harapan usaha terhadap niat menggunakan Sistem Informasi Manajemen Hasil Pengawasan (SIM HP) menunjukkan nilai koefisien jalur sebesar 0,262 . Nilai t diperoleh sebesar 2,762. Nilai tersebut lebih besar dari ttabel $(1,96)$. Hasil ini berarti bahwa harapan usaha memiliki pengaruh positif signifikan terhadap niat menggunakan Sistem Informasi Manajemen Hasil Pengawasan (SIM HP). Pengujian terhadap pengaruh mediasi antar variabel intervening dengan variabel dependen dilakukan dengan perhitungan rumus sobel. Hasil dari kedua pengujian diringkas sebagai berikut: $\mathrm{P}_{1}=0,718, \mathrm{Se}_{1}=0,075, \mathrm{P}_{2}=0,262, \mathrm{Se}_{2}=0,095$

Besarnya koefisien tidak langsung variabel facilitation condition terhadap niat menggunakan Sistem Informasi Manajemen Hasil Pengawasan (SIM HP) merupakan perkalian dari pengaruh variabelfacilitation condition terhadap variabel harapan usaha, sehingga diperoleh sebagai berikut:

$$
\begin{aligned}
\mathrm{P}_{12} & =\mathrm{P}_{1} \cdot \mathrm{P}_{2} \\
& =(0,718)(0,262) \\
& =0,188116
\end{aligned}
$$

Besarnya standar eror tidak langsung facilitation condition terhadap niat menggunakan Sistem Informasi Manajemen Hasil Pengawasan (SIM HP) merupakan perkalian dari pengaruh KM terhadap HU dengan HU terhadap NIAT, sehingga diperoleh sebagai berikut:

$\mathrm{Se}_{12}=\mathrm{P}_{1}^{2} \cdot \mathrm{Se}_{2}^{2}+\mathrm{P}_{2}^{2} \cdot \mathrm{Se}_{1}^{2}+\mathrm{Se}_{1}^{2} \cdot \mathrm{Se}_{2}^{2}$ 


$$
\begin{aligned}
& =\sqrt{ }(0,718)^{2}(0,095)^{2}+(0,262)^{2}(0,075)^{2}+(0,075)^{2}(0,095)^{2} \\
& =\sqrt{ } 0,0047+0,00039+0,0000508 \\
& =\sqrt{ } 0,0051408 \\
& =0,0716993724
\end{aligned}
$$

Dengan demikian nilai uji t diperoleh sebagai berikut:

$\mathrm{T}=\underline{\mathrm{P} 12}=\underline{0,188116}=2,624$

Se12 0,0716993724

Nilai t sebesar 2,624 tersebut lebih besar dari 1,96 yang berarti bahwa parameter mediasi tersebut signifikan. Maka dengan demikian model pengaruh tidak langsung dari variabel facilitation condition terhadap niat menggunakan Sistem Informasi Manajemen Hasil Pengawasan (SIM HP) melalui harapan usaha dapat diterima. Dengan demikian hipotesis 6 diterima. Dalam pengujian hipotesis 6 mediasi dapat dilakukan dengan prosedur yang dikembangkan oleh Sobel (1982) dalam Ghozali(2009) dan dikenal dengan uji Sobel (Sobel test).Pengaruh kondisi memfasilitasi terhadap niat menggunakan Sistem Informasi Manajamen Hasil Pengawasan (SIM HP) dengan harapan usaha sebagai variabel intervening menunjukkan pengaruh yang positif dan signifikan. Pengujian hipotesis keenam ini dilakukan dengan mengetahui pengujian antara variabel harapan usaha dengan niat menggunakan Sistem Informasi Manajamen Hasil Pengawasan (SIM HP) terlebih dahulu. Dari pengujian tersebut diperoleh nilai t-statistik yang lebih besar dari 1,96 yakni sebesar 2,762. Hal ini berarti harapan usaha berpengaruh positif signifikan terhadap niat menggunakan Sistem Informasi Manajamen Hasil Pengawasan (SIM HP). Sedangkan untuk pengaruh mediasi dilakukan pengujian antar variabel intervening dengan variabel dependen dengan menggunakan perhitungan rumus sobel. Dari pengujian tersebut didapat nilai t yang lebih besar dari 1,96 yakni sebesar 2,624. Hal ini berarti bahwa parameter mediasi tersebut signifikan. Maka dengan demikian model pengaruh tidak langsung dari variabel kondisi memfasilitasi terhadap niat menggunakan Sistem Informasi Manajamen Hasil Pengawasan (SIM HP) melalui harapan usaha dapat diterima. Dari kedua pengujian tersebut dapat dikatakan bahwa seorang auditor internal yang memiliki niat yang tinggi untuk menggunakan Sistem Informasi Manajamen Hasil Pengawasan (SIM HP) cenderung akan lebih mudah melalui harapan usaha.

\section{Pengaruh Facilitation Condition terhadap Niat Menggunakan Sistem Informasi Manajemen Hasil Pengawasan (SIM HP) Melalui Harapan Kinerja sebagai Variabel Intervening}

Pengujian hipotesis ketujuh untuk pengujian pengaruh tidak langsung variabel facilitation condition terhadap niat menggunakan Sistem Informasi Manajemen Hasil Pengawasan (SIM HP) melalui harapan kinerja dilakukan dengan terlebih dahulu mengetahui hasil pengujian terhadap pengaruh harapan kinerja terhadap niat menggunakan Sistem Informasi Manajemen Hasil Pengawasan (SIM HP). Pengujian pengaruh mediasi dilakukan dengan menggunakan rumus sobel. Hasil pengujian pengaruh harapan kinerja terhadap niat menggunakan Sistem Informasi Manajemen Hasil Pengawasan (SIM HP) menunjukkan nilai koefisien jalur sebesar 0,368. Nilai t diperoleh sebesar 2,491. Nilai tersebut lebih besar dari ttabel $(1,96)$. Hasil ini berarti bahwa harapan kinerja memiliki pengaruh positif signifikan terhadap niat menggunakan Sistem Informasi Manajemen Hasil Pengawasan (SIM HP). Pengujian terhadap pengaruh mediasi antar variabel intervening dengan variabel dependen dilakukan dengan perhitungan rumus sobel. Hasil dari kedua pengujian diringkas sebagai berikut: $\mathrm{P}_{1}=0,808, \mathrm{Se}_{1}=0,052, \mathrm{P}_{2}=0,368, \mathrm{Se}_{2}=0,148$

Besarnya koefisien tidak langsung variabel facilitation condition terhadap niat menggunakan Sistem Informasi Manajemen Hasil Pengawasan (SIM HP) merupakan 
perkalian dari pengaruh variabelfacilitation condition terhadap variabel harapan kinerja, sehingga diperoleh sebagai berikut:

$$
\begin{aligned}
\mathrm{P}_{12} & =\mathrm{P}_{1} \cdot \mathrm{P}_{2} \\
& =(0,808)(0,368) \\
& =0,297344
\end{aligned}
$$

Besarnya standar eror tidak langsung facilitation condition terhadap niat menggunakan Sistem Informasi Manajemen Hasil Pengawasan (SIM HP) merupakan perkalian dari pengaruh KM terhadap HK dengan HK terhadap NIAT, sehingga diperoleh sebagai berikut:

$$
\begin{aligned}
& \mathrm{Se}_{12}=\sqrt{ } \mathrm{P}_{1}{ }^{2} \cdot \mathrm{Se}_{2}{ }^{2}+\mathrm{P}_{2}{ }^{2} \cdot \mathrm{Se}_{1}{ }^{2}+\mathrm{Se}_{1}{ }^{2} \cdot \mathrm{Se}_{2}{ }^{2} \\
& =\sqrt{ }(0,808)^{2}(0.148)^{2}+(0,368)^{2}(0.052)^{2}+(0,052)^{2}(0,148)^{2} \\
& =\sqrt{ } 0,0143+0,000366+0,0000592 \\
& =\sqrt{ } 0,0147252 \\
& \quad=0,1213474351
\end{aligned}
$$

Dengan demikian nilai uji t diperoleh sebagai berikut:

$\mathrm{T}=\underline{\mathrm{P} 12}=\underline{0,297344}=2,450$

Se12 0,1213474351

Nilai t sebesar 2,450 tersebut lebih besar dari 1,96 yang berarti bahwa parameter mediasi tersebut signifikan. Maka dengan demikian model pengaruh tidak langsung dari variabel facilitation condition terhadap niat menggunakan Sistem Informasi Manajemen Hasil Pengawasan (SIM HP) melalui harapan kinerja dapat diterima. Dengan demikian hipotesis 7 diterima. Dalam pengujian hipotesis 7 mediasi dapat dilakukan dengan prosedur yang dikembangkan oleh Sobel (1982) dalam Ghozali(2009) dan dikenal dengan uji Sobel (Sobel test). Pengaruh kondisi memfasilitasi terhadap niat menggunakan Sistem Informasi Manajamen Hasil Pengawasan (SIM HP) dengan harapan kinerja sebagai variabel intervening menunjukkan hubungan yang positif signifikan. Pengujian hipotesis keenam ini dilakukan dengan mengetahui pengujian antara variabel harapan usaha dengan niat menggunakan Sistem Informasi Manajamen Hasil Pengawasan (SIM HP) terlebih dahulu. Dari pengujian tersebut diperoleh nilai t-statistik yang lebih besar dari 1,96 yakni sebesar 2,491. Hal ini berarti harapan usaha berpengaruh positif signifikan terhadap niat menggunakan Sistem Informasi Manajamen Hasil Pengawasan (SIM HP). Sedangkan untuk pengaruh mediasi dilakukan pengujian antar variabel intervening dengan variabel dependen dengan menggunakan perhitungan rumus sobel. Dari pengujian tersebut didapat nilai t yang lebih besar dari 1,96 yakni sebesar 2,450. Hal ini berarti bahwa parameter mediasi tersebut signifikan. Maka dengan demikian model pengaruh tidak langsung dari variabel kondisi memfasilitasi terhadap niat menggunakan Sistem Informasi Manajamen Hasil Pengawasan (SIM HP) melalui harapan kinerja diterima. Dari kedua pengujian tersebut dapat dikatakan bahwa seorang auditor internal yang memiliki niat yang tinggi untuk menggunakan Sistem Informasi Manajamen Hasil Pengawasan (SIM HP) cenderung akan lebih bermanfaat melalui harapan kinerja.

\section{SIMPULAN DAN SARAN}

Penelitian ini membahas tentang suatu model yang menguji pengaruhfacilitation condition terhadap niat menggunakan Sistem Informasi Manajemen Hasil Pengawasan (SIM HP) dengan harapan usaha dan harapan kinerja sebagai variabel intervening. Berdasarkan pengujian SEM (Structural Equation Model) sebagai berikut:1) Pengaruh kondisi memfasilitasi berpengaruh positif dan signifikanterhadap harapan usaha. Artinya, semakin tinggi kondisi memfasilitasi seperti pelatihan yang diberikan auditor semakin memudahkan, maka semakin tinggi harapan usaha.2) Pengaruh kondisi memfasilitasi berpengaruh positif dan signifikanterhadap harapan kinerja. Artinya, semakin tinggi kondisi memfasilitasi (sarana 
dan prasarana) diberikan kepada auditor, maka semakin tinggi harapan kinerja.3) Pengaruh kondisi memfasilitasi berpengaruh positif dan signifikanterhadap niat menggunakan sistem informasi manajemen hasil pengawasan. Artinya, semakin tinggi kondisi memfasilitasi seperti dukungan sarana dan prasarana diberikan kepada auditor, maka semakin tinggi niat menggunakan sistem informasi manajemen hasil pengawasan.4) Pengaruh harapan usaha berpengaruh positif dan signifikanterhadap niat menggunakan sistem informasi manajemen hasil pengawasan. Artinya, semakin tinggi usaha yang dilakukan oleh auditor semakin memudahkan auditor dalam niat menggunakan, maka semakin tinggi niat menggunakansistem informasi manajemen hasil pengawasan.5) Pengaruh harapan kinerja berpengaruh positif dan signifikanterhadap niat menggunakan sistem informasi manajemen hasil pengawasan. Artinya, semakin tinggi manfaat yang dirasakan oleh auditor seperti meningkatkan kualitas pengawasan, maka semakin tinggi niat menggunakansistem informasi manajemen hasil pengawasan.6) Harapan usaha berhasil memediasi pengaruh kondisi memfasilitasi terhadap niat menggunakan Sistem Informasi Manajemen Hasil Pengawasan (SIM HP). Artinya, semakin tinggi peran harapan usaha dalam memediasi pengaruh maka semakin tinggi pula peran kondisi memfasilitasi secara tidak langsung terhadap niat menggunakan Sistem Informasi Manajemen Hasil Pengawasan (SIM HP).7) Harapan kinerja berhasil memediasi pengaruh kondisi memfasilitasi terhadap niat menggunakan Sistem Informasi Manajemen Hasil Pengawasan (SIM HP). Artinya, semakin tinggi peran harapan kierja dalam memediasi pengaruh maka semakin tinggi pula peran kondisi memfasilitasi secara tidak langsung terhadap niat menggunakan Sistem Informasi Manajemen Hasil Pengawasan (SIM HP).

Dari hasil analisis dan kesimpulan yang sudah dijelaskan, peneliti bemaksud untuk memberikan saran yang semoga akan menjadi masukan bagi semua pihak, antara lain:Berikut ini beberapa saran dari peneliti yang berkaitan dengan keterbatasan antara lain: 1) Perlu dilakukan pengembangan instrumen penelitian yaitu disesuaikan dengan kondisi dan lingkungan dari obyek yang diteliti dan memperluas lingkup penelitian (wilayah penelitian) dengan memperbanyak sampel dan pemilihan sampel yang acak sehingga hasil penelitian dapat di generalisasi, 2)Menambahkan variabel faktor eksternal lainnya seperti (faktor sosial) dimana dari variabel tersebut dapat mempengaruhi niat untuk menggunakan sistem informasi, 3)Menambah responden dalam penelitian ini agar tidak hanya mengisi kuesioner tetapi bisa juga melalui wawancara sehingga peneliti lebih mengetahui gambaran atau keadaan mengenai obyek penelitian.

\section{DAFTAR PUSTAKA}

Ajzen, I., (1980). "Understanding Attitude and Predicting Social Behavior, Prentice-hall", nglewood scliffs, nj, Vol. 17 No. 25, pp. 123-145.

Bedard, J.C., Jackson, C., Ettredge, M.L. and Johnstone, K.M. (2003). "The effect of training on auditors' acceptance of an electronic work system", InternationalJournal of Accounting Information Systems, Vol. 4, pp. 227-250.

Curtis and Elizabeth., (2014). "Modeling Voluntary CAAT Utilization Decision in Auditing". Managerial Auditing Journal, Vol. 29 No. 4, pp. 211-238.

Davis (1989). "Perceived Usefulness, Perceived Ease of Use, and Acceptance ofInformation System Technolog”.MIS Quarterly, Vol.13, No.3. pp.319-339.

Dwi., Achyar dan Ardi., (2009). "Variabel anteseden dan Konsekuensi Pemanfaatan Sistem Informasi (Studi Empiris pada Pemerintahan Kabupaten di Pulau Madura)”Jurnal Akuntansi dan Keuangan Indonesia, Vol. 6 No. 1, Juni 2009.

Ghozali., (2006). Structural Equation Modeling Metode Alternatif dengan Partial Least Square, Badan Penerbit Universitas Diponegoro, Semarang.

Ghozali., (2009). Structural Equation Modelling, Metode Alternatif dengan Patrial Least Square (PLS). Badan Penerbit Universitas Dipenegoro. Semarang. 
Gonzalez, G.C., Sharma, P.N. and Galletta, D.F., (2012). "The Antecedent of the System Information Auditing”, International Journal of Accounting Information Systems, Vol. 13 No. 3, pp. 248-262.

Pennington, R.R., Kelton, A.S. and DeVries., D.D. (2006). "The effects of qualitative overload on technology acceptance”, Journal of Information Systems, Vol. 20, pp. 2536.

Pusat Pendidikan dan Pelatihan Pengawasan Badan Pengawasan Keuangan dan Pembangunan, (2008). Diklat Sertifikasi JFA Tingkat Pembentukan Auditor Ahli. Edisi Keempat, Jakarta.

Venkatesh, (2003)."Predicting different conceptualizations of system use: the competing roles of behavioral intention, facilitating conditions, and behavioral expectation",MIS Quarterly, Vol. 32 No. 3, pp. 483-502.

Venkatesh and Bala, H., (2008). "Technology acceptance model 3 and a researchagenda on interventions", Decision Sciences, Vol. 39 No. 2, pp. 273-315. 